\title{
Evaluating the atmospheric drivers leading to the December 2014 flood in Schleswig-Holstein, Germany
}

\author{
Nils H. Schade \\ Federal Maritime and Hydrographic Agency (BSH), 20359 Hamburg, Germany \\ Correspondence to: Nils H. Schade (nils.schade@bsh.de)
}

Received: 19 December 2016 - Discussion started: 2 January 2017

Revised: 11 April 2017 - Accepted: 9 May 2017 - Published: 14 June 2017

\begin{abstract}
Regional analyses of atmospheric conditions that may cause flooding of important transport infrastructure (railway tracks, highways/roads, rivers/channels) and subsequent adaptation measures are part of topic 1 of the network of experts initiated by the German Federal Ministry of Transport and Digital Infrastructure (BMVI). As an example case study, the December 2014 flood in Schleswig-Holstein, Germany, was investigated. Atmospheric conditions at the onset of the flood event are described and evaluated with respect to the general weather circulation, initial wetness, and event precipitation. Persistent, predominantly westerly general weather circulations (GWCs) directed several low-pressure systems over the North Sea to Schleswig-Holstein during December 2014, accompanied by prolonged rainfall and finally a strong precipitation event in southern Schleswig-Holstein, causing several inland gauges to exceed their, by then maximum, water levels. Results show that the antecedent precipitation index (API) is able to reflect the soil moisture conditions and, in combination with the maximum 3-day precipitation sum (R3d), to capture the two main drivers finally leading to the flood: (1) the initial wetness of north-western Schleswig-Holstein and (2) strong event precipitation in southern and eastern Schleswig-Holstein from 21 to 23 December; at the same time, both indices exceeded their respective 5year return periods. Further, trend analyses show that both API and R3d have been increasing during recent years, while regional patterns match the north-eastward shift of cyclone pathways, leading to a higher risk of flooding in Schleswig-Holstein. Within the network of experts, investigations of these and further indices/drivers for earth system changes (e.g. wind surge and sea level rise) derived from observations, reanalyses, and regional climate model data are planned for all German coastal areas. Results can be expected to lead to improved adaptation measures to floods under climate change conditions wherever catchments have to be drained and infrastructures and ecosystems may be harmed.
\end{abstract}

\section{Introduction}

In December 2014, predominant westerly general weather circulations (GWCs) caused a major Baltic inflow (MIB) event (see, e.g., Lehmann et al., 2016; Post and Lehmann, 2016). At the same time, persistent rainfall in combination with an extreme precipitation event from 21 to 23 December led to the flooding of several catchment areas in SchleswigHolstein, Germany, located between the North and Baltic seas. Both events mark independent atmospheric and hydrologic responses to the GWC, illustrating the importance of interdisciplinary research in this area. In this regard, the region Schleswig-Holstein is a potent "blue spot" dealing with multiple drivers for earth system changes in the North and Baltic seas region. It is affected in many ways by extremes, especially under climate change conditions: (1) considerable areas in the southern parts lie beneath sea level and have to be drained artificially; (2) long-lasting and heavy rainfall events lead to increased flooding possibility in economically relevant parts of the country. The North and Baltic seas Canal (NOK; http://www.wsa-kiel.wsv.de/Nord-Ostsee-Kanal) for example, also known as the "Kiel Canal", is the most important waterway in this region. In fact, with over 30000 passages per year, it is the busiest artificial waterway worldwide (e.g. Lübbecke et al., 2014). But the NOK is not only impor- 
tant for transportation; it also serves as drainage of several catchments, e.g. the upper Eider basin, while the water level has to be regulated within a few decimetres to keep shipping traffic possible. Therefore, the atmospherical and hydrological conditions have to be monitored carefully concerning extremes and changes therein.

The physical conditions of the North Sea control both meteorology and hydrology in northern European coastal regions (see, e.g., Attema and Lenderink, 2014): dominant factors are the actual wind and water levels - including future sea level rise - and the predominant GWC. According to Randall et al. (2007), large-scale and prolonged extreme events result from a persistent GWC in conjunction with air-sea interactions (and air and soil). These interactions are of particular importance for coastal areas. Hydrological extremes, like flooding events, are thus caused rather by unusual and unfavourable combinations of different influencing factors than by extremes of these factors themselves (Klemes, 1993). For instance, storm surges in combination with heavy but not extreme rain fall may lead to problematic drainage situations due to high seaward water levels (see, e.g., Wahl et al., 2015). According to investigations by Kew et al. (2013) conducted in the Rhine delta, the probability of extreme surge conditions following extreme 20-day precipitation sums is even 3 times higher than estimated from treating extreme surge and discharge probabilities independently. Also, a combination of initial catchment wetness and a single heavy yet not extreme precipitation event alone may lead to flooding. Berthet et al. (2009) and Pathiraja et al. (2012) show that catchment wetness is actually a crucial parameter in flood forecasting. Given the difficulties in estimating the catchment wetness, arising from inadequate records of soil moisture conditions (e.g. Albergel et al., 2013), Woldemeskel and Sharma (2016) point out the role of antecedent precipitation as a surrogate variable for any flood assessment under global warming conditions.

In the following, the observed situation, predominant GWC, and precipitation indices describing soil moisture condition and event precipitation are investigated for the December 2014 flood in Schleswig-Holstein, Germany. An extensive evaluation concerning the hydrology based on catchment gauge data has already been undertaken by the Landesbetrieb für Küstenschutz, Nationalpark und Meeresschutz Schleswig-Holstein (LKN-SH) and the Landesamt für Landwirtschaft, Umwelt und ländliche Räume SchleswigHolstein (LLUR-SH) in a separate report (LKN-SH and LLUR-SH, 2015). Therefore, the focus of this paper lies on the atmospheric conditions leading to the flood. The aim is to show that (1) the method of Schröter et al. (2015) to classify nationwide flood events can be applied on a regional scale and that (2) the indices used, namely the antecedent precipitation index (API) and 3-day precipitation sum (R3d), can add useful information about changing local flood regimes in a warming climate. Evidence is presented by investigating the significant trends in recent years.
Within topic 1 of the network of experts of the German Federal Ministry of Transport and Digital Infrastructure (BMVI, http://www.bmvi-expertennetzwerk.de), all methods used in this paper are planned to be applied to reanalyses and (regional) climate model data as well. This way, a first glimpse into possible future changes might be achieved without the need to run complex and expensive hydrological models. Further, API and R3d can be derived directly from climate model precipitation output, which makes them effective and easy to apply. Therefore, results can be expected to be of great value for the work in national and international projects dealing with the adaptation of transport and infrastructure under future climate change.

The remainder of this paper is structured as follows: first, data and methods (Sect. 2) are described. An evaluation of the atmospheric drivers leading to the December 2014 flood and a discussion of the findings are offered in Sect. 3. Finally, concluding remarks are given in Sect. 4 and an outlook in Sect. 5.

\section{Data and methodology}

\subsection{General weather circulation}

Two different objective GWC classification methods were compared to describe the situation in Schleswig-Holstein (SH) during December 2014: (1) the modified Lamb weather types (LWTs; Jenkinson and Collison, 1977) used at the Federal Maritime and Hydrographic Agency (BSH; Löwe, 2005) with a model centre over the central North Sea, and (2) the objective classification (OWTC; Dittmann et al., 1995; Bissolli and Dittmann, 2001) of the German Meteorological Service (DWD) with a model centre over central Germany. Further differences are the input parameters: while LWT is based solely on sea level pressure data, here the NCEP/NCAR Reanalysis 1 (Kalnay et al., 1996), at 16 grid points over northern Europe, OWTC input data include air pressure, temperature, wind, and water vapour content on different height levels derived from the current operational GME (Global Model Extended) of DWD (http://www.dwd.de/EN/ourservices/ wetterlagenklassifikation/wetterlagenklassifikation). Further, OWTC output parameters include cyclonality on two height levels (950 and $500 \mathrm{hPa}$ ) and a humidity index ("wet" and "dry") that describes the precipitable water content of the atmosphere compared to the long-term daily mean. LWT output, however, includes a gale index in four categories (from "no gale" to "very severe gale") derived from the strength of the geostrophic flow and the vorticity.

\subsection{Precipitation and soil moisture indices}

Schröter et al. (2015) have investigated 76 nationwide flood events that affected at least $10 \%$ of the German river catchments over a period from 1960 to 2009 and ranked them con- 
cerning their severity. Further included were the floods from 1954 and 2013 (Blöschl et al., 2013). The investigations are based on the data set from Uhlemann et al. (2010) using time series of daily mean discharge records at 162 gauge stations of the German Water and Shipment Administration (WSV) and the German Federal Institute of Hydrology (BfG). Additionally, Schröter et al. (2015) used daily precipitation sums from the REGNIE data set (see, e.g., Rauthe et al., 2013) provided by DWD with a spatial resolution of $1 \times 1 \mathrm{~km}$ to describe the meteorological situation of these events. The basic idea in using this approach is the assumption that a combination of extreme initial wetness (i.e. oversaturation of the soil) and a strong but not extraordinary event precipitation leads to flooding. These factors were evaluated by means of two indices: (1) the maximum R3d as a trigger of the flood, calculated at each grid point separately within a window of \pm 10 days around the onset of the flood event, and (2) the initial API, calculated from the sum of daily precipitation at each grid point $R_{i}(x y)$ and weighted with respect to the time $\operatorname{span}(m=30$ days) of rainfall occurrence prior to the R3d to ensure a clear separation of both indices; see Eq. (1):

$\operatorname{API}(x, y)=\sum_{i=1}^{30} k^{i} R_{i}(x y,(m-i))$.

Here, $i$ marks the day prior to the $\mathrm{R} 3 \mathrm{~d}$ and $k=0.9$ a depletion constant that approximates the decrease in soil moisture due to evapotranspiration and percolation to deeper soil layers. Using this approach, the rainfall at day 1 prior the R3d is weighted highest.

Both indices were calculated using REGNIE's daily precipitation sums for the December 2014 flood. The constant $k$ was not changed; however, future investigations could include regional soil types at a high resolution (if accessible). Further, it should be noted that the coastal regions were excluded by Schröter et al. (2015) since floods might be affected by the water level conditions in the North and Baltic seas, i.e. the possibilities for drainage (K. Schröter, personal communication, 2016). Since sea gauge data did not show any extremes and drainage was possible at all times during the December 2014 flood (see Sect. 3.4), a comparative analysis is justified and might help to point to regional risk potentials, even for spatially limited flood events.

Furthermore, the Matlab toolbox WAFO (WAFO-group, 2000) was used for the statistical evaluation: according to Schröter et al. (2015), the yearly maximum 3-day precipitation sums and the respective 30-day antecedent precipitation were calculated at each REGNIE grid point. Then, 5 to 100-year return periods (5-100yRPs) were derived at each grid point using the Gumbel distribution over the base period 1960-2009.

\subsection{Trend analyses}

Mean trends above the $95 \%$ significance level for the five highest R3d (R3dfivemax) and API (APIfivemax) values per year were calculated over 30-year running intervals from 1960-1989 to 1985-2014 for the Kiel Canal catchment (EZG NOK), SH, and all of Germany (D). Instead of the yearly maximum alone, the five highest events per year were chosen so as to obtain more reliable and robust statistics. A modified version of the Mann-Kendall test (see Hamed and Rao, 1998) was used to determine significant trends, avoiding misleading results due to autocorrelation (in case autocorrelation is greater than 0 ). All trends were calculated at each grid point separately. Then, area means were derived.

\subsection{Gauge data}

Results from gauge data from the LKN-SH and LLUR-SH (2015) report will also be presented to investigate the applicability of the chosen precipitation indices. A map showing maximum water levels at all catchment gauges in SchleswigHolstein during the December 2014 flood is kindly provided by Thomas Hirschhäuser (LLUR-SH). Furthermore, in-depth analyses of the hydrological situation including discharges and statistical evaluations can be found in the LKNSH and LLUR-SH (2015) report. The most relevant results are presented in Sect. 3.6.

\section{Results and discussion}

The December 2014 was dominated by westerly GWCs lasting for several weeks. Therefore, a number of low-pressure systems were led from the North Atlantic over northern Europe in quick succession. As an example, the systems Alexandra and Billie (11/12/2014), both characterized by wet maritime air and stormy conditions with gusts from 17 to $28 \mathrm{~m} \mathrm{~s}^{-1}$ observed all over SH and Hamburg (HH), are shown in Fig. 1.

\subsection{General weather circulation (GWC)}

In general, both classification methods show predominant westerly GWCs from 5 December onwards with northwesterly (NW) situations during the heavy precipitation event from 21 to 23 December (Table 1): OWTC shows humid conditions; LWT shows "gale". However, differences are apparent during the first precipitation event: the cores of the low-pressure systems are centred far north, categorized by LWT as severe gale (Alexandra) and gale (Billie) with southwesterly (SW) cyclonic flow (Fig. 2a, b). OWTC on the other hand categorized a NW anticyclonic flow and dry conditions. An explanation provides the relevant model centre; OWTC is focused over central Germany, while LWT is ideally centred in the North Sea. Since most of southern and central Ger- 


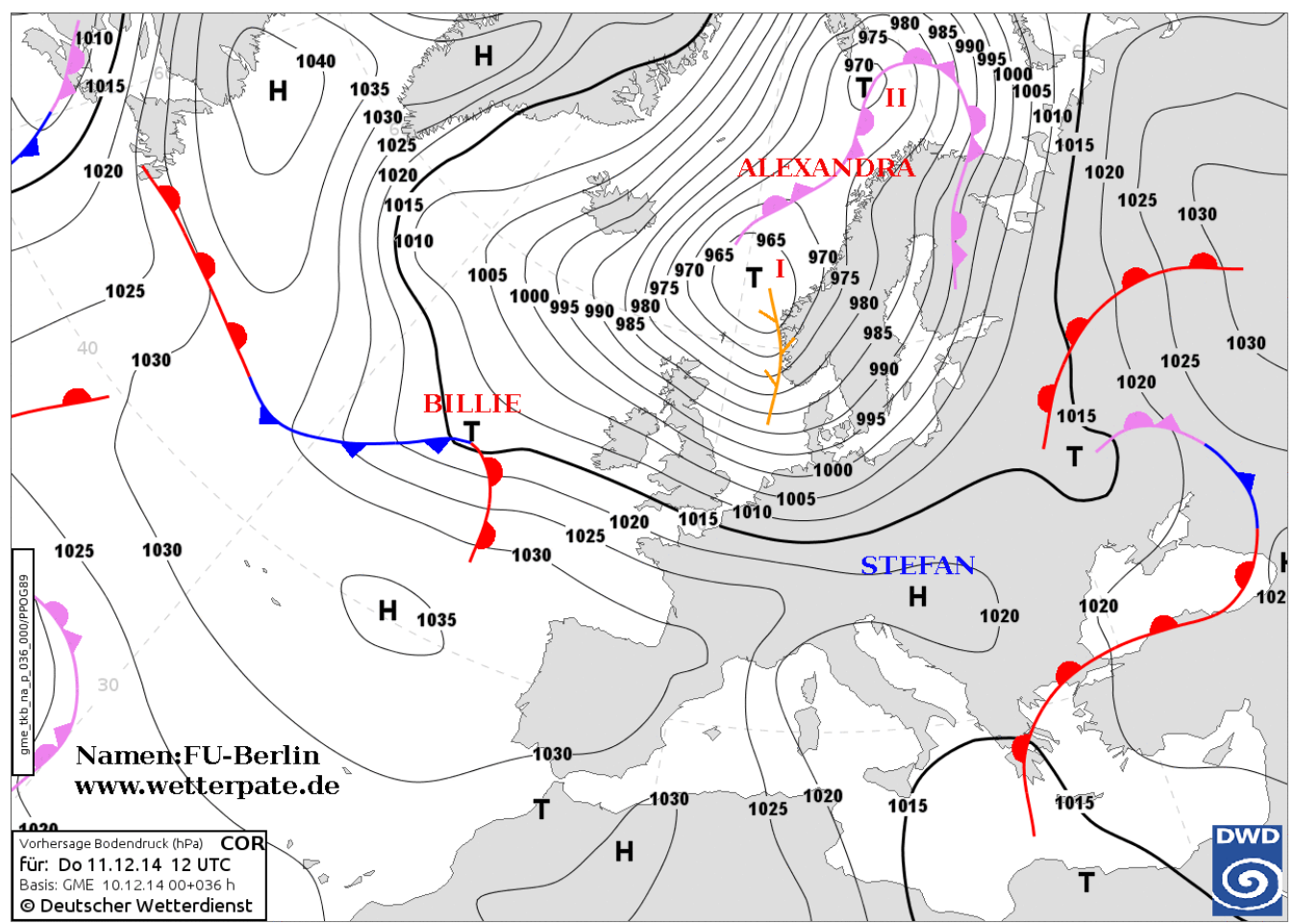

Figure 1. Sea level pressure prediction for Thursday, 11 December 2014, showing the low-pressure systems Alexandra and Billie in quick succession. Image credit: FU Berlin, www.met.fu-berlin.de (last access: 20 February 2015).

many was unaffected by this precipitation event, most of the model domain was indeed dry.

It becomes obvious that the use of the classification method is subject to several factors. One of these specifies that the method should be suitable to the region of interest and capture its unique features. In this case, LWT provides slightly better results due to its focus on the North Sea and the fact that OWTC misses wet days during the first precipitation event. Nevertheless, both GWC analyses clearly show that not only one specific weather type but the succession of similar (westerly) types was important to the overall high soil moisture conditions, i.e. in generating prolonged rainfall, especially in northern Schleswig-Holstein. Additionally, the extreme precipitation event in southern Schleswig-Holstein was caused by a succession of NW types from 19 to 23 December (5 days; LWT) and 17 to 23 December (7 days; OWTC). Considering the mean life time of the NW type of 1.82 days (base period 1971-2000; Löwe et al., 2013, their Table 2-10), the event was extraordinary for this region.

\subsection{Precipitation}

Above-average monthly precipitation amounts between 80 and $160 \mathrm{~mm}$ were recorded at the German coasts during December 2014; local monthly means were exceeded by more than double that value and old records were broken. In SH, values of $175 \mathrm{~mm}$ up to $225 \mathrm{~mm}$ were reached (Fig. 3a), which corresponds to about $225-300 \%$ of the long-term means (Fig. 3b). All over the rest of Germany, December 2014 was unremarkable, with maximum mean values around or clearly below those of the reference period (19611990).

Looking at daily precipitation sums from the REGNIE data set, two main rainfall periods can be distinguished: one from 10 to 12 December, more pronounced in northern $\mathrm{SH}$, and one from 18 to 24 December (Fig. 4). Maximum daily precipitation was detected from 22 to 23 December in southern $\mathrm{SH}$ and $\mathrm{HH}$, with local values exceeding $50 \mathrm{~mm}$ corresponding to the standard monthly mean values.

As seen in Fig. 4a-c, the first rainfall period begins in far north-eastern (NE) SH on 10 December slowly progressing to the south. It further shows that not only SH was affected during this event: pronounced rainfall was detected north of the Eifel region on 12 December. Figure 4d-f display the main precipitation event from 21 to 23 December. Now mainly northern Germany is affected, especially southern SH on 22 December. Values are comparable to daily precipitation sums from selected DWD stations presented in Fig. 5 showing that REGNIE (solid black lines) fits the station data (bar plots) well. Only the highest maximum values are slightly underestimated: highest values are found at Wittenborn, north of Hamburg, with over $50 \mathrm{~mm}$ on 22 December (see Fig. 4e), about $30 \mathrm{~mm}$ at Schleswig in central $\mathrm{SH}$, and over $20 \mathrm{~mm}$ at Leck in northern $\mathrm{SH}$ on 22 December 

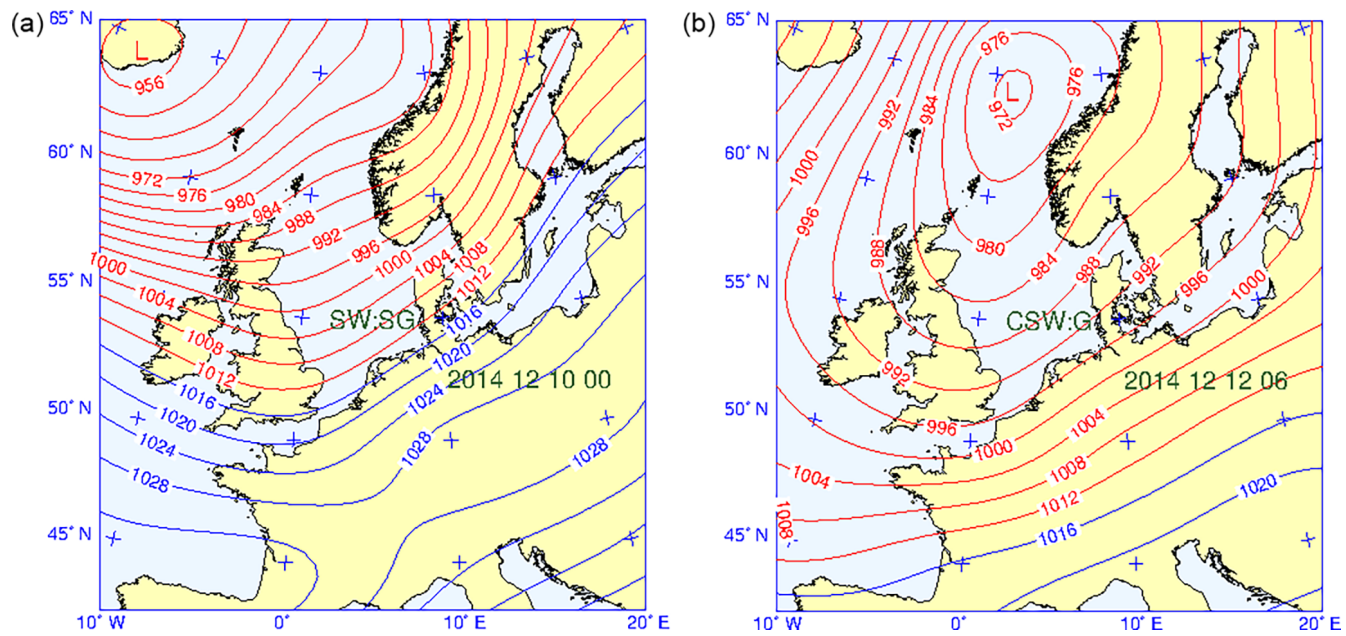

Figure 2. Classification of the general weather circulation (GWC) after the modified Lamb weather types used at BSH for (a) the lowpressure systems Alexandra (classification: south-west (SW) with severe gale (SW)) and (b) Billie (classification: cyclonal south-west (CSW) with gale (G)). Image credit: P. Löwe (BSH Hamburg).
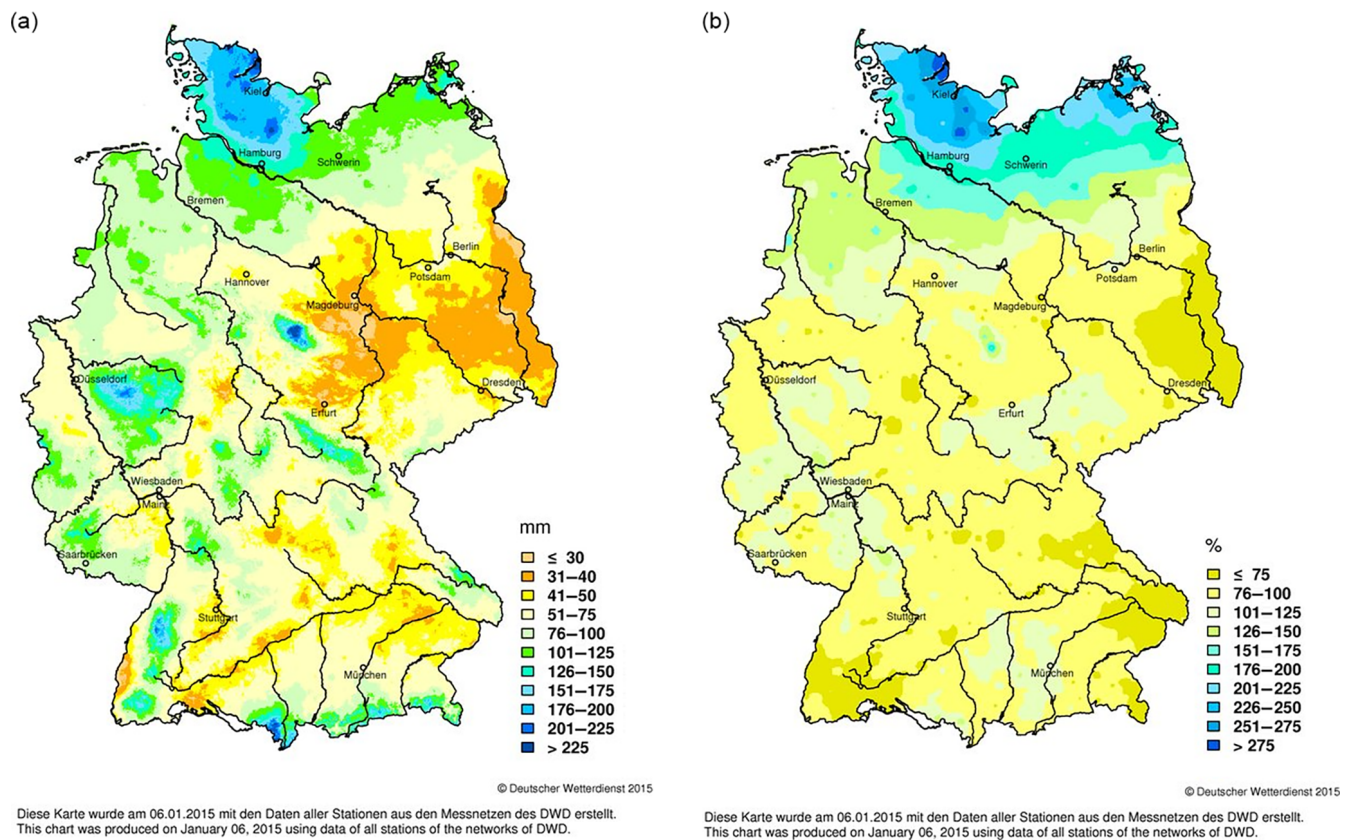

Figure 3. (a) Precipitation sums in Germany in millimetres, December 2014, and (b) their differences in percent to the long-term mean of 1961-1990. Image credit: DWD, www.dwd.de (last access: 6 January 2015).

(see Fig. 4f). The first rainfall period is captured as well, with maximum values on 11 and 12 December (see Fig. 4b, c).

\subsection{Soil moisture}

Additional investigations using modelled soil moisture data from DWD's Agrometeorological Research Centre (ZAMF) for sandy loam soil and cultivation with sugar beets show highest values in the $\mathrm{SH}$ region, with up to $139 \% \mathrm{nFK}$ (effective field moisture capacity) in the north for 21 Decem- ber 2014 (start date of the corresponding event precipitation). Values decrease southward but never below $100 \% \mathrm{nFK}$ except in the south of SH (Fig. 6a). The unit \% nFK describes the saturation in percent of effective field capacity of the upper $60 \mathrm{~cm}$ of soil. If soil moisture exceeds $100 \% \mathrm{nFK}$, the actual water content is higher than is usable for plants (DWD, 2016), i.e. as in most of northern and central SH at the onset of the main precipitation event. The south to north gradient is in accordance with precipitation data, showing a slow progression of rainfall events from north to south (see Sect. 3.2). 

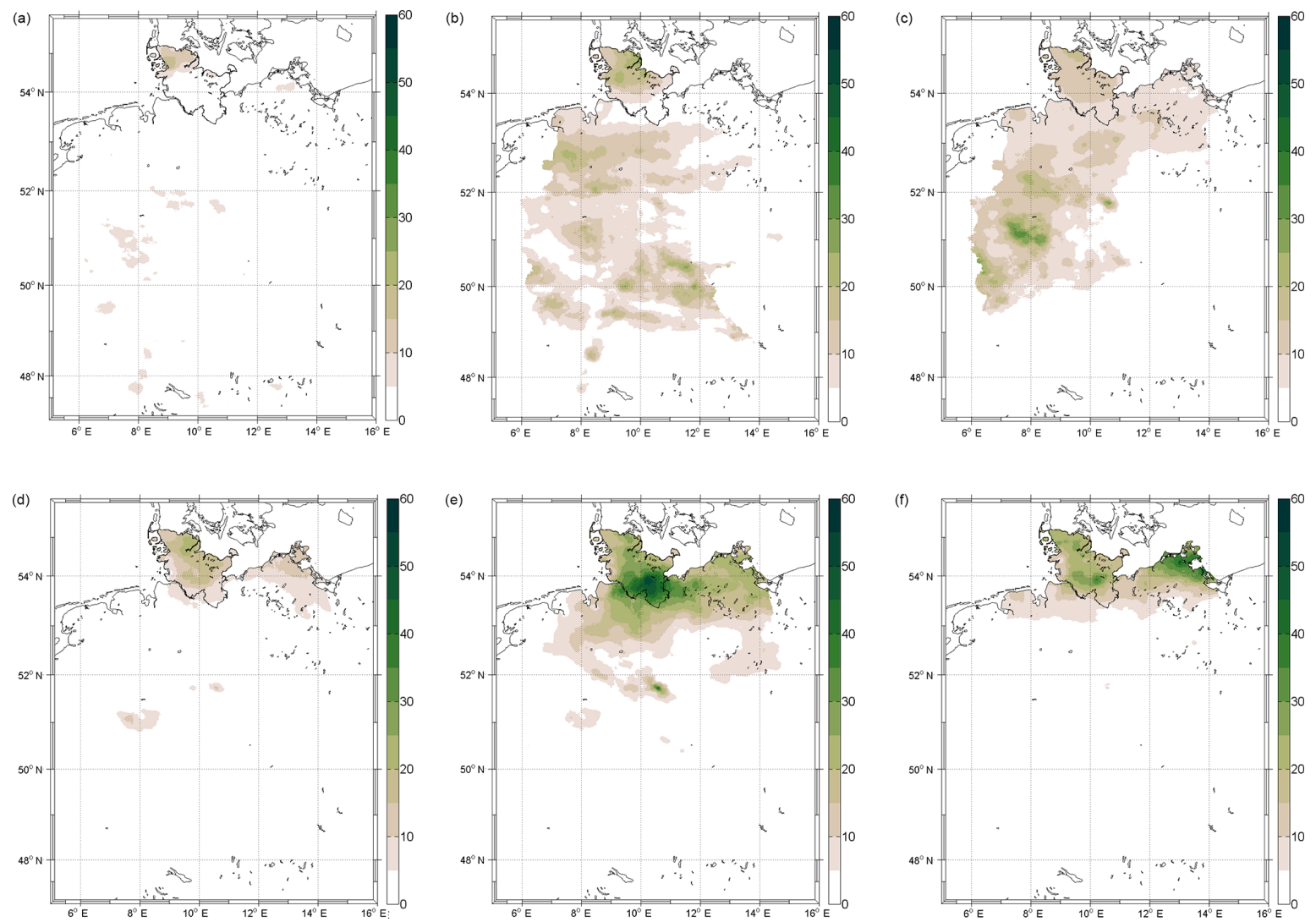

Figure 4. Daily sums of REGNIE precipitation data in millimetres for the first event, 10-12 December 2014 (a-c), and the main precipitation event, 21-23 December 2014 (d-f). The boundaries of Schleswig-Holstein are marked in black.
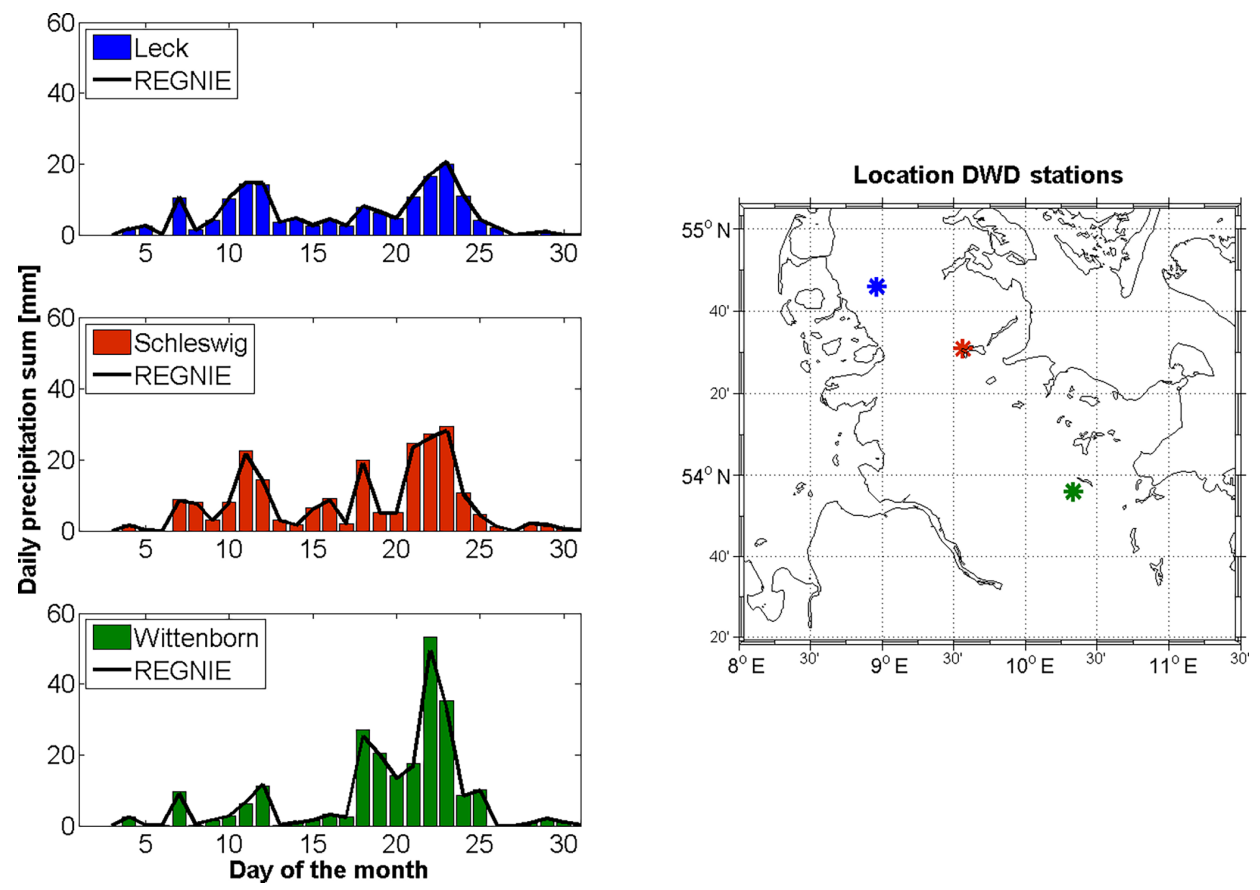

Figure 5. Daily precipitation sums at DWD stations in northern (Leck), central (Schleswig), and southern (Wittenborn) Schleswig-Holstein, December 2014. Black lines indicate REGNIE daily precipitation sums at the closest respective grid points. 

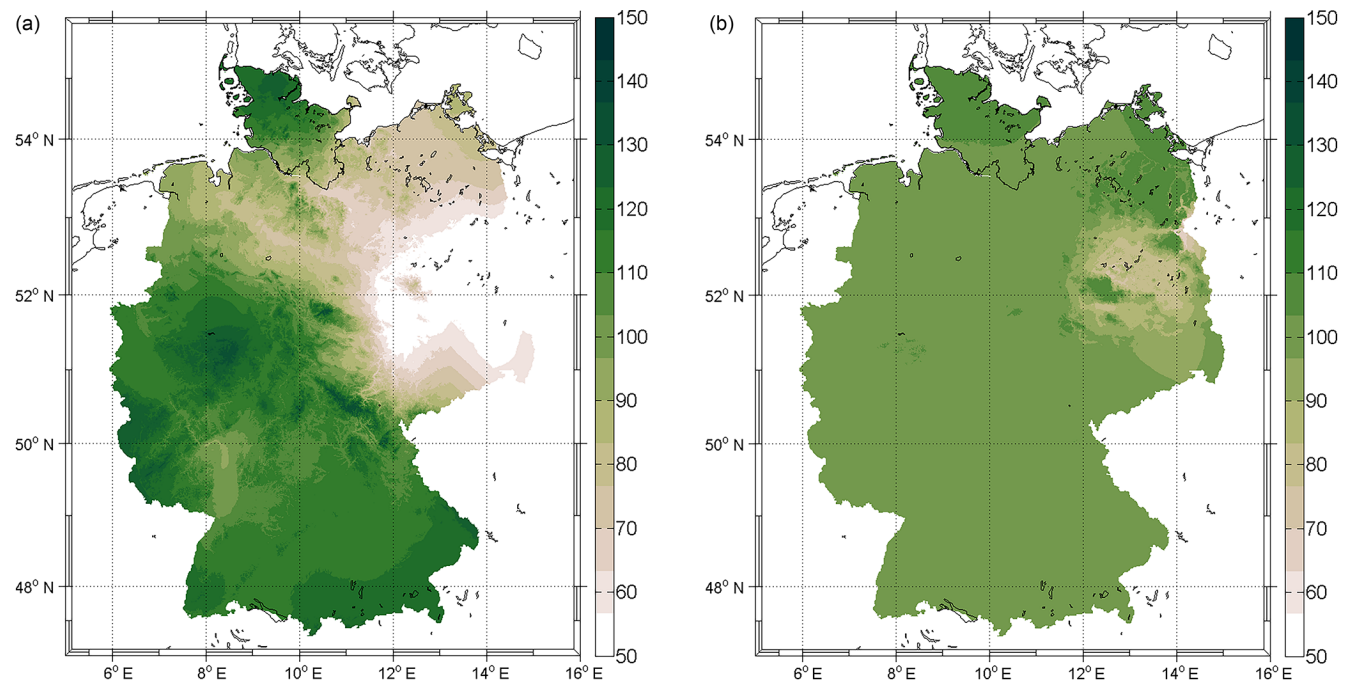

Figure 6. (a) Soil moisture in \% nFK for sandy loam soil and (b) for loamy sand soil, 21 December 2014 (Model calculations by ZAMF, Braunschweig, Germany). The boundaries of Schleswig-Holstein are marked in black.

ZAMF also provides soil moisture data for loamy sand soil and cultivation with winter grain. Using this data, values in northern and central SH are between 105 and $110 \% \mathrm{nFK}$ for the same date (Fig. 6b). It should be noted that neither the actual soil differentiation nor the degree of sealing is part of the model chain, and locally, this might be of importance (see, e.g., Apel et al., 2016). Nevertheless, both soil types show the same oversaturated regions in $\mathrm{SH}$ with some minor differences in the Fehmarn area (eastern $\mathrm{SH}$ ).

\subsection{Event precipitation - R3d}

Figure 7 shows the 3-day precipitation sum R3d for the December 2014 flood in Schleswig-Holstein (Fig. 7a) and its corresponding ratio to the 5-year return period (5yRP, Fig. 7b). The scaling for R3d is set according to Schröter et al. (2015). Clearly, the main contiguous part of the event precipitation is restricted to northern Germany, with some spots in central and southern Germany. R3d shows rather moderate maximum values of $109 \mathrm{~mm}$ north of Hamburg compared to the flood in 2013 with maximum values up to $300 \mathrm{~mm}$ (see Schröter et al., 2015, their Fig. 5, left). These differences can be explained mainly with the origin of both events: the flood 2013 was triggered by a quasi-stationary trough over central Europe in May and June leading low-pressure systems with hot and humid air masses at their flanks from SE Europe northwards. Additional orographic effects caused by the mountain ridges in central Europe, large-scale uplifting downstream from the low-pressure systems, and embedded convective processes finally led to prolonged and extended rainfall (e.g. Belz et al., 2013, 2014; Stein and Malitz, 2013). The December 2014 flood was triggered by low-pressure systems with North Atlantic air masses exclusively and appeared in winter when relatively cold air cannot hold as much water.
Areas with R3d exceeding the 5yRP are centred north of Hamburg, the eastern NOK region, the catchments Stör and Krückau, and at the coasts of Mecklenburg-Vorpommern (Fig. 7b). Higher return periods can be found north of Hamburg in the area of Wittenborn (see Fig. 4). Here, values even exceed 100yRPs locally, but due to the fact that the base period only spans 50 years, return periods over 100 years are becoming increasingly uncertain (rule of thumb: 2 times the observational time span gives the maximum return period to be statistically sound). Therefore, the cut has been made at 100 years. Nevertheless, this shows how extraordinary this event was for this region.

\subsection{Antecedent precipitation index - API}

Figure 8 shows the corresponding values for the API, again, scaled according to Schröter et al. (2015). Maximum API values of $41.5 \mathrm{~mm}$ (Fig. 8a) are well below those of the flood 2013 (see Schröter et al., 2015, their Fig. 7, left) and can be found in NW SH, which is in fair agreement with the soil moisture data (see Fig. 6a). In contrast to R3d, the 5yRPs for API are exceeded only in NW SH (Fig. 8b), with maximum values corresponding to $20 \mathrm{yRP}$.

It is obvious that antecedent precipitation in combination with the maximum precipitation event led to SH-wide flooding in 2014 (Figs. 7, 8): areas that were struck by heavy rainfall did not need additional initial wetness to be flooded; areas with high antecedent precipitation were saturated already and needed only small amounts of additional event precipitation. In this regard, the importance of both indices to describe this flood accurately is illustrated. Furthermore, ongoing investigations in the NOK catchment area suggest that R3d and API are promising indicators or predictors to describe problematic situations in the canal's operational routine. How- 

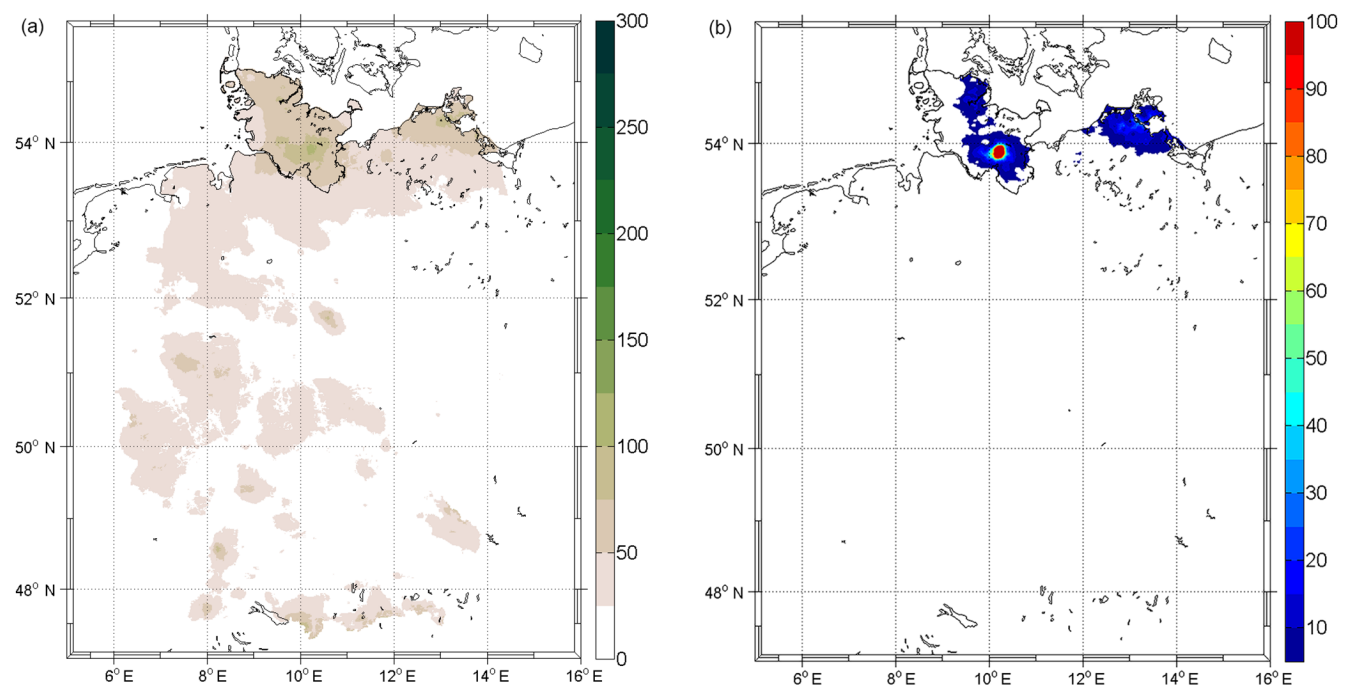

Figure 7. (a) Three-day event precipitation (R3d) in millimetres and (b) corresponding return periods (base period 1960-2009) for the December 2014 flood in Schleswig-Holstein, Germany, calculated from REGNIE data following the method described in Schröter et al. (2015). The boundaries of Schleswig-Holstein are marked in black.

ever, since many other influencing factors like wind surge, locking of ships, dewatering, ferry traffic, etc. are involved, pinpointing the respective factors to one single event is difficult, and therefore, accurate estimations of the consistency for regional investigations cannot be given at this point yet.

\subsection{Gauge data}

The LKN-SH and LLUR-SH (2015) report points out that more than a third (66 out of 184) of inland gauges in SH exceeded the, thus far, highest high-water level (HHW) during the December 2014 flood (Fig. 9). Almost all of these gauges are located in areas affected by high R3d values in southern and north-eastern SH or high API values in north-western SH (see Figs. 7, 8).

Furthermore, 14 gauges exceeded high waters with low probability, i.e. $200 \mathrm{yr}$ return periods (HW200; according to HWRM-RL, 2007). Two more gauges exceeded their $100 \mathrm{yr}$ return periods (HW100) and eight gauges their $10 \mathrm{yr}$ return periods (HW10; LKN-SH and LLUR-SH, 2015, their Fig. 46). Regarding discharges, three gauges exceeded their respective $200 \mathrm{yr}$ return periods, four more their $100 \mathrm{yr}$ return periods, and five more their $50 \mathrm{yr}$ return periods ( $\mathrm{LKN}-\mathrm{SH}$ and LLUR-SH, 2015, their Fig. 80). All of these gauges are located in areas affected by R3d or API.

More than $80 \%$ exceeded the mean high-water level (MHW), while gauges not reaching the MHW were mainly sea gauges located in the North Sea. Return periods of half a year were hardly exceeded here (Jens Möller, BSH, personal communication, 2015). Therefore, the December 2014 flood could have been much worse if an additional storm surge had hindered the drainage of the SH catchments into the North Sea.

\subsection{Trend analyses - R3d and API}

Figure 10 shows significant mean 30-year running trends for the North and Baltic seas Canal catchment area (EZG NOK), $\mathrm{SH}$, and D for the five highest R3d and API events per year. Obviously, trends are not only highly dependent on the respective base period, showing considerable interannual variation, but on the area under investigation as well: while trends for R3d are positive in SH (with one exception) and the EZG NOK during the whole period, they become negative during recent years looking at Germany as a whole. Keeping in mind that cyclone pathways and connected extreme precipitation events are shifting north-eastwards (e.g. Stendel et al., 2016), SH and the EZG NOK will probably experience more and heavier extreme situations in the future. Furthermore, a clear separation of NE and SW Germany regarding significant R3d trends is evident in recent years, exemplarily shown for the period 1983-2012 (Fig. 11a): trends are positive in NE Germany and negative in SW Germany with only some local spots (e.g. mountainous areas) showing opposing trends. This separation also is in accordance with the shifting cyclone pathways.

API trends (Fig. 11b) are negative for all areas in the beginning, change to high positive values during the 1980, and have settled at lower values since. Again, D shows the smallest values since the NE-SW separation is also evident but not as articulated as for R3d. Nevertheless, API can also be expected to increase more strongly in the north-east under climate change conditions, leading to wetter soil and an increased risk of flooding in these areas. Combined with the higher probability of extreme precipitation events, especially for northern Germany (SH, EZG NOK), the risk increases even further. 

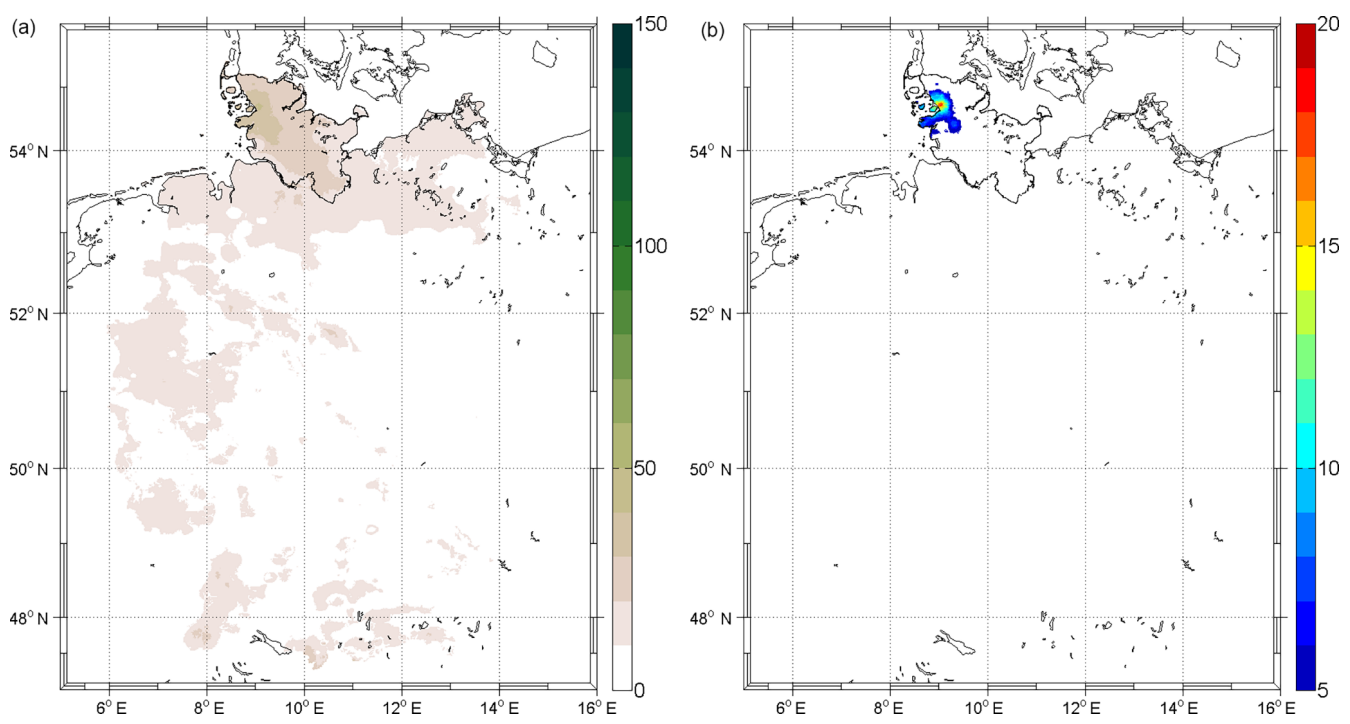

Figure 8. As in Fig. 7, but for the API.

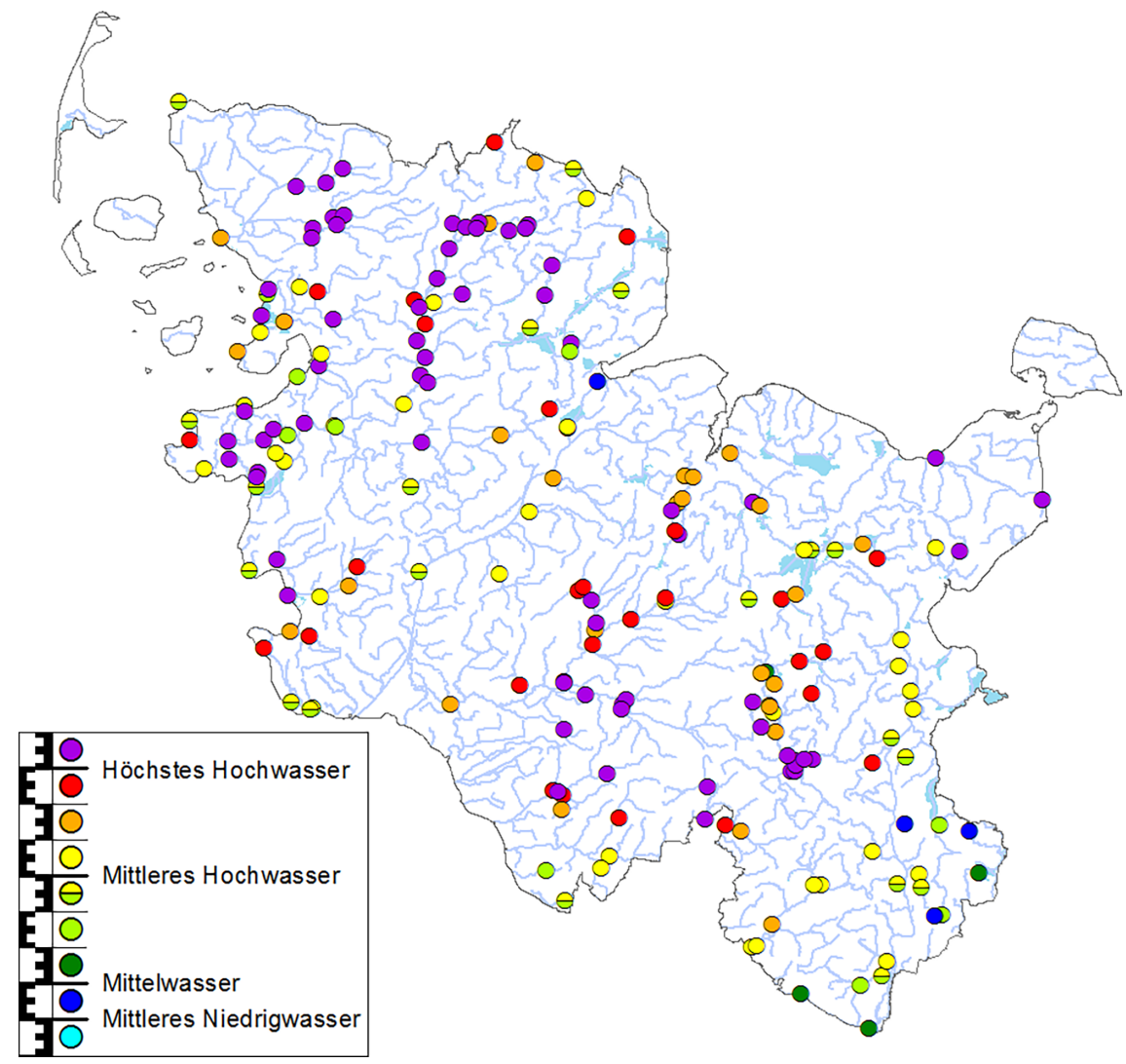

Figure 9. Gauge data in Schleswig-Holstein, showing exceedance of highest high-water levels (mauve), medium high-water levels (yellow to red), medium water levels (green to yellow), medium low-water levels (dark blue), and lower levels (light blue) during the December 2014 flood. This map from the LKN-SH and LLUR-SH (2005) report was kindly provided by Thomas Hirschhäuser (LLUR-SH). 
(a)

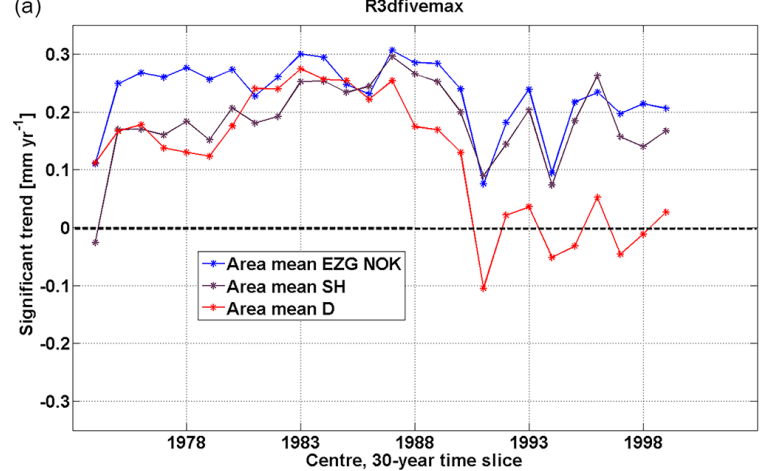

(b) APlfivemax

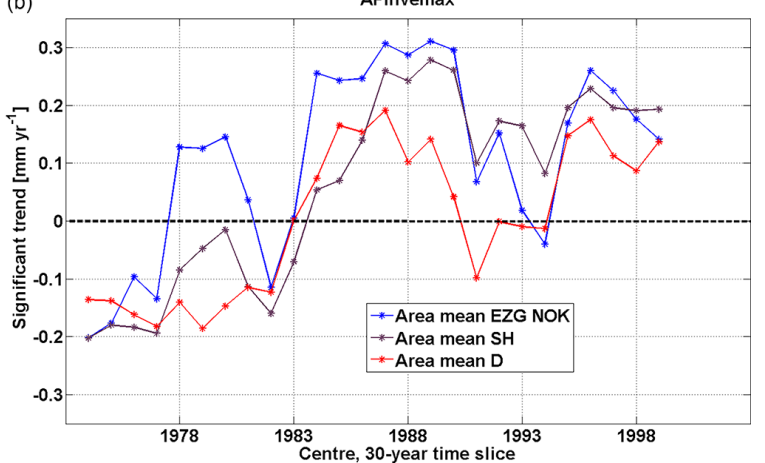

Figure 10. Mean significant trends (above $95 \%$ significance level) over 30-year running intervals from 1960-1989 to 1985-2014 in millimetres per year for the five highest (a) 3-day event precipitation (R3dfivemax) and (b) antecedent precipitation indices (APIfivemax) per year for the Kiel Canal catchment (blue), Schleswig-Holstein (mauve), and all of Germany (red). The centre year of the respective 30-year time slices is marked on the $x$ axis.
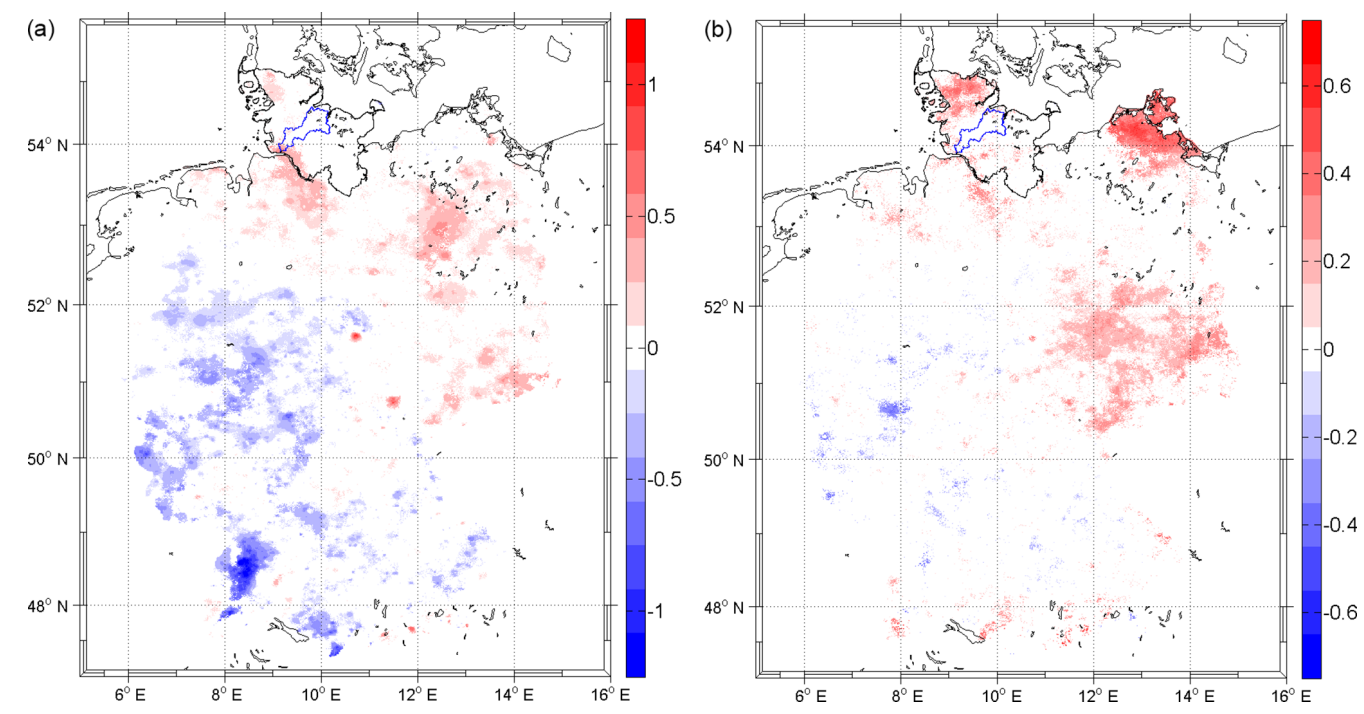

Figure 11. Significant trends (above $95 \%$ significance level) in millimetres per year for the five highest (a) 3-day event precipitation (R3dfivemax) and (b) antecedent precipitation indices (APIfivemax) per year in Germany; base period 1983-2012. The boundaries of Schleswig-Holstein are marked in black, boundaries of the Kiel Canal catchment in blue.

\section{Summary and conclusion}

In the end, the December 2014 flood in Schleswig-Holstein did not turn out to be as dramatic as it could have been: the flood management worked well and the infrastructure withstood the water masses for the most part (only a few dyke breaks and a slope slide of about $1.5 \mathrm{~km}$ on the motorway A1 were reported). An additional simultaneous storm surge, however, could have caused severe problems, e.g. by cutting off the possibilities for drainage due to high low-water levels. The relevant meteorological situation did indeed exist: persistent westerly weather circulations with frequent lowpressure systems partly classified as gales or even severe gales. The fact that all catchments could be drained at all tides and retention areas were utilized to a greater extent (see
LKN-SH and LLUR-SH, 2015) may have prevented greater damage.

The indices R3d and API used nationwide by Schröter et al. (2015) can be applied on the regional scale as well and give an accurate evaluation of the initial wetness and the heavy rainfall event that led to the flood in December 2014. Almost all inland gauges exceeding their highest high-water values, return periods (HW200, HW100, HW10), and discharges (HQ200, HQ100, HQ50) during this flood are located in areas influenced by R3d and API. API, especially, captures the highest soil moisture conditions modelled by ZAMF at the onset of the R3d event quite well. This is of particular interest for future evaluation of reanalyses and climate models because this method only needs precipitation data as input, which makes it a cost-effective estimation of the 
Table 1. Modified Lamb weather types (LWT; BSH) and objective classification (OWTC; DWD), December 2014. Letters in the LWT column indicate the following from left to right: the classified weather type, cyclonality index (A or C), predominant wind direction at ground level, and gale index. Characters in the OWTC column indicate the following from left to right: weather type number, predominant wind direction at $700 \mathrm{hPa}$, cyclonality (A or Z) at 950 and $500 \mathrm{hPa}$, and humidity index (T or F). LWT gale indices are printed in italic (gale) and bold and italic (severe gale) letters; OWTC wet weather types are given in bold letters. "NUL" indicates no gale.

\begin{tabular}{|c|c|c|}
\hline Date & LWT & OWTC \\
\hline $01 / 12 / 2014$ & SE A SE NUL & $38 \mathrm{SO} Z \mathrm{ZF}$ \\
\hline $02 / 12 / 2014$ & NE A NE NUL & $21 \mathrm{XX} Z \mathrm{~A} T$ \\
\hline $03 / 12 / 2014$ & A A NE NUL & $31 \mathrm{XX}$ Z Z T \\
\hline $04 / 12 / 2014$ & A A SE NUL & $38 \mathrm{SO} Z \mathrm{Z} \mathrm{F}$ \\
\hline $05 / 12 / 2014$ & C C SW NUL & $9 \mathrm{SW} A \mathrm{~A} F$ \\
\hline $06 / 12 / 2014$ & A A NW NUL & $6 \times X A A F$ \\
\hline $07 / 12 / 2014$ & SW A SW NUL & $4 \mathrm{SW}$ A A T \\
\hline $08 / 12 / 2014$ & NW C NW NUL & $15 \mathrm{NW}$ A Z T \\
\hline 09/12/2014 & SW A SW NUL & 11 XX A Z T \\
\hline $10 / 12 / 2014$ & $S W C S W S G$ & $5 \mathrm{NW} \mathrm{A} \mathrm{A} \mathrm{T}$ \\
\hline $11 / 12 / 2014$ & $S W C S W G$ & $15 \mathrm{NW}$ A Z T \\
\hline $12 / 12 / 2014$ & $C C S W G$ & $29 \mathrm{SW} \mathrm{Z} \mathrm{A} \mathrm{F}$ \\
\hline $13 / 12 / 2014$ & NW A NW NUL & $4 \mathrm{SW}$ A A T \\
\hline $14 / 12 / 2014$ & $S W A S W G$ & $19 \mathrm{SW}$ A Z F \\
\hline $15 / 12 / 2014$ & SW C SW NUL & $9 \mathrm{SW}$ A A F \\
\hline $16 / 12 / 2014$ & NW A NW NUL & $19 \mathrm{SW}$ A Z F \\
\hline $17 / 12 / 2014$ & SW C SW NUL & $40 \mathrm{NW} Z \mathrm{Z}$ F \\
\hline $18 / 12 / 2014$ & SW C SW NUL & 10 NW A A F \\
\hline $19 / 12 / 2014$ & $N W C N W G$ & 10 NW A A F \\
\hline $20 / 12 / 2014$ & $N W C N W G$ & $15 \mathrm{NW}$ A Z T \\
\hline $21 / 12 / 2014$ & NW A NW NUL & $5 \mathrm{NW}$ A A T \\
\hline $22 / 12 / 2014$ & $N W A N W G$ & 10 NW A A F \\
\hline $23 / 12 / 2014$ & $N W A N W G$ & 10 NW A A F \\
\hline $24 / 12 / 2014$ & C C NW NUL & $9 \mathrm{SW}$ A A F \\
\hline $25 / 12 / 2014$ & NW C NW NUL & $35 \mathrm{NW} \mathrm{Z} \mathrm{Z} \mathrm{T}$ \\
\hline $26 / 12 / 2014$ & A A SW NUL & $15 \mathrm{NW}$ A Z T \\
\hline $27 / 12 / 2014$ & C C SE NUL & $31 \mathrm{XX}$ Z Z T \\
\hline $28 / 12 / 2014$ & A A NE NUL & 2 NOA A T \\
\hline $29 / 12 / 2014$ & A A NW NUL & $35 \mathrm{NW} Z \mathrm{ZZ} \mathrm{T}$ \\
\hline $30 / 12 / 2014$ & A A NW NUL & $5 \mathrm{NW}$ A A T \\
\hline $31 / 12 / 2014$ & A A SW NUL & 7 NOA A F \\
\hline
\end{tabular}

soil moisture without running additional soil models. Since catchment wetness prior to extreme precipitation events is of high importance for flood forecasts (see Berthet et al., 2009; Pathiraja et al., 2012), API seems to be a promising surrogate, especially in the case of poor observational soil moisture data (see Woldemeskel and Sharma, 2016). Nevertheless, additional high-resolution information about the actual soil type, i.e. in calculating the respective depletion constant, could be an advantage. Other influencing factors and drivers like snowmelt, frost, droughts, etc. could be taken into con- sideration as well since each catchment exhibits its own system of dependencies (see, e.g., Valiuškevičius et al., 2016).

Trend analyses indicate an increasing risk of flood-prone situations in Schleswig-Holstein due to increasing R3d and API values over the last decades. Taking sea level rise into account (e.g. Quante et al., 2016; Wahl et al., 2013), leading to increased ground water levels and, therefore, higher initial soil moisture, flood protection and improved drainage of the affected catchments becomes even more relevant.

\section{Outlook}

Future work within topic 1 of the network of experts will include amongst other things the evaluation of long-term changes at gauge stations in the North and Baltic seas (Möller and Heinrich, 2016) and applying the above-described precipitation indices to reanalyses and regional climate models (RCMs). Since precipitation extremes are expected to increase in the future (e.g. Nikulin et al., 2010; Kharin et al., 2013; Scoccimarro et al., 2013), the number of potentially harmful situations can be expected to increase accordingly. In fact, the trend analyses presented above show that R3d and API are already increasing. How big the impact will be compared to other potent drivers for coastal changes (e.g. wind surge and sea level rise) is one major aspect of this ongoing research.

In addition, several other impact studies and pilot projects will investigate future planning and management of transportation under climate change scenarios, e.g. the NOK, Fehmarnsund, and coastal infrastructure. The latter may be harmed by increasing wind-induced water levels in the North Sea as well (Gaslikova et al., 2012). New high-resolution reanalyses like COSMO-REA6 (Bollmeyer et al., 2015) by the Hans-Ertel-Zentrum (HErZ), based on DWD's operational forecast model COnsortium for Small-Scale MOdelling limited-area model (COSMO-LAM; Schättler et al., 2011), will improve the hindcast evaluations and serve as input for RCM runs. In a first comparison, Kaiser-Weiss et al. (2015) have already shown advantages over global reanalyses for ground level wind data, especially in coastal and mountainous regions due to the improved spatial $(6 \times 6 \mathrm{~km})$ and temporal (hourly) resolution. The same might be expected for the evaluation of (extreme) precipitation and derived indices, like R3d and API.

Further investigations could include extending R3d and API to extreme and abnormal events (see Müller and Kaspar, 2014; Müller et al., 2015) via seasonality and a varying size of the catchment areas, which is of particular interest for regional investigations. Also, the use of the extreme climate indices defined by the Expert Team on Climate Change Detection and Indices (ETCCDI; see, e.g., Sillmann et al., 2013a, b) might prove relevant. 
Data availability. DWD daily REGNIE data are freely available for download at ftp://ftp-cdc.dwd.de/pub/CDC/grids_germany/ daily/regnie (last access: 8 June 2017).

DWD daily station data are freely available for download at ftp:// ftp-cdc.dwd.de/pub/CDC/observations_germany/climate/daily (last access: 8 June 2017).

DWD daily OWTC data are freely available for download at http://www.dwd.de/DE/leistungen/wetterlagenklassifikation/ online_wlkvorhersage.txt?view=nasPublication $\& n n=16102 \quad$ (last access: 8 June 2017).

Competing interests. The author declares that he has no conflict of interest.

Acknowledgements. The research leading to this paper was conducted as part of topic 1 of the network of experts initiated by the German Federal Ministry of Transport and Digital Infrastructure (BMVI). REGNIE, OWTC, and station data have been provided by the German Meteorological Service (DWD), soil moisture data by DWD's Agrometeorological Research Centre (ZAMF). NCEP/NCAR R1 has been provided by the NOAA/OAR/ESRL PSD, Boulder, Colorado, USA, from their website at http://www.esrl.noaa.gov/psd. The administrative boundaries of Schleswig-Holstein were extracted from the GADM database of Global Administrative Areas (www.gadm.org); boundaries of the Kiel Canal catchment were provided by the Landesamt für Landwirtschaft, Umwelt und ländliche Räume Schleswig-Holstein (LLUR-SH). Thanks go to the BSH and DWD teams for fruitful discussions and support. Personal thanks to Peter Löwe, Thomas Hirschhäuser, and Kai Schröter.

Edited by: A. Rutgersson

Reviewed by: two anonymous referees

\section{References}

Albergel, C., Dorigo, W., Reichle, R. H., Balsamo, G., de Rosnay, P., Muñoz-Sabater, J., Isaksen, L., de Jeu, R., and Wagner, W.: Skill and global trend analysis of soil moisture from reanalyses and microwave remote sensing, J. Hydrometeorol., 14, 12591277, https://doi.org/10.1175/JHM-D-12-0161.1, 2013.

Apel, H., Martínez Trepat, O., Hung, N. N., Chinh, D. T., Merz, B., and Dung, N. V.: Combined fluvial and pluvial urban flood hazard analysis: concept development and application to Can Tho city, Mekong Delta, Vietnam, Nat. Hazards Earth Syst. Sci., 16, 941-961, https://doi.org/10.5194/nhess-16-941-2016, 2016.

Attema, J. J. and Lenderink, G.: The influence of the North Sea on coastal precipitation in the Netherlands in the present-day and future climate, Clim. Dynam., 42, 505-519, https://doi.org/10.1007/s00382-013-1665-4, 2014.

Belz, J. U., Becker, A., Böhm, U., Bremicker, M., Brockmann, H., Busch, N., Gratzki, A., Hammer, M., Hatz, M., Krahe, P., Krüger, F., Löpmeier, F.-J., Malitz, G., Meißner, D., Moser, H., Mürlebach, M., Nordmeyer, L., Rademacher, S., Riediger, U., Rose, J., Schmidt, T., Schorr, M., Spanknebel, H.-G., Supper-Nilges, D., Vogelbacher, A., Walther, P., and Wiechmann, W.: Län- derübergreifende Analyse des Juni-Hochwassers 2013, Bericht der BFG-1797, 74 pp., 2013.

Belz, J. U., Adler, M., Baschek, B., Bergfeld-Wiedemann, T., Brockmann, H., Busch, N., Claes, J., Daedlow, K., Hammer, M., Hatz, M., Hillebrand, G., Hübner, G., Klein, B., Kleisinger, C., Krahe, P., Larina-Pooth, M., Meißner, D., Mothes, D., Mürlebach, M., Nilson, E., Otto, W., Promny, M., Rademacher, S., Schöl, A., Schriever, S., Schubert, B., Schwandt, D., und Viergutz C.: Das Hochwasserextrem des Jahres 2013 in Deutschland: Dokumentation und Analyse, Koblenz, Bundesanstalt für Gewässerkunde (BfG), Mitteilungen, 31, 232 pp., doi.bafg.de/ BfG/2014/BfG_Mitteilungen_31.2014.pdf, 2014.

Berthet, L., Andréassian, V., Perrin, C., and Javelle, P.: How crucial is it to account for the antecedent moisture conditions in flood forecasting? Comparison of event-based and continuous approaches on 178 catchments, Hydrol. Earth Syst. Sci., 13, 819831, https://doi.org/10.5194/hess-13-819-2009, 2009.

Bissolli, P., and Dittmann, E.: The objective weather types classification of the German Weather Service and its possibilities of application to environmental and meteorological investigations, Meteorol. Z., 10, 253-260, https://doi.org/10.1127/09412948/2001/0010-0253, 2001.

Blöschl, G., Nester, T., Komma, J., Parajka, J., and Perdigão, R. A. P.: The June 2013 flood in the Upper Danube Basin, and comparisons with the 2002, 1954 and 1899 floods, Hydrol. Earth Syst. Sci., 17, 5197-5212, https://doi.org/10.5194/hess-17-5197-2013, 2013.

Bollmeyer, C., Keller, J. D., Ohlwein, C., Wahl, S., Crewell, S., Friederichs, P., Hense, A., Keune, J., Kneifel, S., Pscheidt, I., Redl, S., and Steinke, S.: Towards a high-resolution regional reanalysis for the European CORDEX domain, Q. J. Roy. Meteor. Soc., 141, 1-15, https://doi.org/10.1002/qj.2486, 2015.

Dittmann, E., Barth, S., Müller-Westermeier, G., and Lang, J.: Objektive Wetterlagenklassifikation, Berichte des Deutschen Wetterdienstes Nr. 197, Deutscher Wetterdienst, Offenbach am Main, 1995.

DWD: Dokumentation - Bodenfeuchte, Stand: Februar 2016, available at: https://www.dwd.de/DE/fachnutzer/landwirtschaft/ dokumentationen/allgemein/bf_erlaeuterungen.pdf (last access: 8 June 2017), 2016.

Gaslikova, L., Grabemann, I., and Groll, N.: Changes in North Sea storm surge conditions for four transient future climate realizations, Nat. Hazards, 66, 1501-1518, https://doi.org/10.1007/s11069-012-0279-1, 2012.

Hamed, K. H. and Rao, A. R.: A modified Mann-Kendall trend test for autocorrelated data, J. Hydrol., 204, 182-196, https://doi.org/10.1016/S0022-1694(97)00125-X, 1998.

HWRM-RL: Directive 2007/60/EC of the European Parliament and of the Council of 23 October 2007 on the assessment and the management of flood risks, Official Journal of the European Union L 288/27, 27-34, available at: http://data.europa.eu/eli/dir/ 2007/60/oj, 6 November 2007.

Jenkinson, A. F. and Collison, F. K.: An initial climatology of gales over the North Sea, Synoptic Climatology Branch Memorandum, 62, 18 pp., UK Met Office, Bracknell, 1977.

Kaiser-Weiss, A. K., Kaspar, F., Heene, V., Borsche, M., Tan, D. G. H., Poli, P., Obregon, A., and Gregow, H.: Comparison of regional and global reanalysis near-surface winds with sta- 
tion observations over Germany, Adv. Sci. Res., 12, 187-198, https://doi.org/10.5194/asr-12-187-2015, 2015.

Kalnay, E., Kanamitsu, M., Kistler, R., Collins, W., Deaven, D., Gandin, L., Iredell, M., Saha, S., White, G., Wollen, J., Zhu, Y., Chelliah, M., Ebisuzaki, W., Higgins, W., Janowiak, J., Mo, K. C., Ropelewski, C., Wang, J., Leetma, Y. A., Reynolds, R., Jenne, R., and Joseph, D.: The NCEP/NCAR 40-Year Reanalysis Project, B. Am. Meteorol. Soc., 77, 437-471, https://doi.org/10.1175/15200477(1996)077<0437:TNYRP>2.0.CO;2; 1996.

Kew, S. F., Selten, F. M., Lenderink, G., and Hazeleger, W.: The simultaneous occurrence of surge and discharge extremes for the Rhine delta, Nat. Hazards Earth Syst. Sci., 13, 2017-2029, https://doi.org/10.5194/nhess-13-2017-2013, 2013.

Kharin, S., Zwiers, F., Zhang, X., and Wehner, M.: Changes in temperature and precipitation extremes in the CMIP5 ensemble, Climatic Change, 119, 345-357, https://doi.org/10.1007/s10584013-0705-8, 2013.

Klemes, V.: Probability of extreme hydrometeorological events a different approach, in: Extreme Hydrological Events: Precipitation, Floods and Droughts, IAHS, Yokohama, 213, 167-176, 1993.

Lehmann, A., Höflich, K., Post, P., and Myrberg, K.: Pathways of deep cyclones associated with large volume changes (LVCs) and major Baltic inflows (MBIs), in: Conference Proceedings of 1st Baltic Earth Conference "Multiple drivers for Earth system changes in the Baltic Sea region", Nida, Lithuania, International Baltic Earth Secretariat Publication No. 9, 222 pp., 2016.

LKN-SH and LLUR-SH: Bericht zum Weihnachtshochwasser 2014, 118 pp., available at: https://www.schleswig-holstein. de/DE/Fachinhalte/H/hydrologie_niederschlag/Downloads/ hochwasserbericht2014.html (last access: 8 June 2017), 2015.

Löwe, P. (Ed.): Nordseezustand 2003, Berichte des BSH, Nr. 38, Bundesamt für Seeschifffahrt und Hydrographie, Hamburg und Rostock, 220 pp., available at: http://www.bsh.de/de/ Produkte/Buecher/Berichte_/Bericht38/index.jsp (last access: 8 June 2017), 2005.

Löwe, P., Klein, H., and Weigelt-Krenz, S. (Eds): System Nordsee - 2006 \& 2007: Zustand und Entwicklungen, Berichte des BSH, Nr. 49, Bundesamt für Seeschifffahrt und Hydrographie, Hamburg und Rostock, 303 pp., available at: http://www.bsh.de/ de/Produkte/Buecher/Berichte_/Bericht49/index.jsp (last access: 8 June 2017), 2013.

Lübbecke, E., Lübbecke, M. E., and Möhring, R. H.: Ship traffic optimization for the Kiel Canal, Technical Report 4681, available at: https://www.researchgate.net/profile/Marco_Luebbecke/ publication/268982408_Ship_Traffic_Optimization_for_the_ Kiel_Canal/links/547e26ba0cf2d2200ede95e9.pdf (last access: 8 June 2017), 2014.

Möller, J. and Heinrich, H.: The new established Expertennetzwerk: The focus-region "Südwestliches Schleswig-Holstein" and a case study to long term changes in the intensity of extreme water levels, in: Conference Proceedings of 1st Baltic Earth Conference "Multiple drivers for Earth system changes in the Baltic Sea region", Nida, Lithuania, International Baltic Earth Secretariat Publication No. 9, 222 pp., 2016.

Müller, M. and Kaspar, M.: Event-adjusted evaluation of weather and climate extremes, Nat. Hazards Earth Syst. Sci., 14, 473483, https://doi.org/10.5194/nhess-14-473-2014, 2014.
Müller, M., Kašpar, M., Valeriánová, A., Crhová, L., Holtanová, E., and Gvoždíková, B.: Novel indices for the comparison of precipitation extremes and floods: an example from the Czech territory, Hydrol. Earth Syst. Sci., 19, 4641-4652, https://doi.org/10.5194/hess-19-4641-2015, 2015.

Nikulin, G., Kjellström, E., Hansson, U., Strandberg, G., and Ullerstig, A.: Evaluation and future projections of temperature, precipitation and wind extremes over Europe in an ensemble of regional climate simulations, Tellus, 63, 41-55, https://doi.org/10.1111/j.1600-0870.2010.00466.x, 2010.

Pathiraja, S., Westra, S., and Sharma, A.: Why continuous simulation? The role of antecedent moisture in design flood estimation, Water Resour. Res., 48, W06534, https://doi.org/10.1029/2011WR010997, 2012.

Post, P., and Lehmann, A.: Assessment of long time series of atmospheric circulation patterns forcing large volume changes and major inflows to the Baltic Sea, in: Conference Proceedings of 1st Baltic Earth Conference "Multiple drivers for Earth system changes in the Baltic Sea region", Nida, Lithuania, International Baltic Earth Secretariat Publication No. 9, 222 pp., 2016.

Quante, M., Colijn, F., and Nöhren, I.: The North Sea Region Climate Change Assessment (NOSCCA): What happens in the south west of BACC?, in: Conference Proceedings of 1st Baltic Earth Conference "Multiple drivers for Earth system changes in the Baltic Sea region", Nida, Lithuania, International Baltic Earth Secretariat Publication No. 9, 222 pp., 2016.

Randall, D.A., Wood, R.A., Bony, S., Colman, R., Fichefet, T., Fyfe, J., Kattsov, V., Pitman, A., Shukla, J., Srinivasan, J., Stouffer, R. J., Sumi, A., and Taylor, K. E.: Climate models and their evaluation. Climate Change 2007: the Physical Science Basis, Contribution of Working Group I to the Fourth Assessment Report of the Intergovernmental Panel on Climate Change, Cambridge University Press, Cambridge, UK.

Rauthe, M., Steiner, H., Riediger, U., Mazurkiewicz, A., and Gratzki, A.: A Central European precipitation climatology Part I: Generation and validation of a high-resolution gridded daily data set (HYRAS), Meteorol. Z., 22, 235-256, https://doi.org/10.1127/0941-2948/2013/0436, 2013.

Schättler, U., Doms, G., and Schraff, C.: A description of the nonhydrostatic regional model LM - Part VII: Users' guide, Technical report, Deutscher Wetterdienst, Offenbach, Germany, 132 pp., 2011.

Schröter, K., Kunz, M., Elmer, F., Mühr, B., and Merz, B.: What made the June 2013 flood in Germany an exceptional event? A hydro-meteorological evaluation, Hydrol. Earth Syst. Sci., 19, 309-327, https://doi.org/10.5194/hess-19-309-2015, 2015.

Scoccimarro, E., Gualdi, S., Bellucci, A., Zampieri, M., and Navarra, A.: Heavy precipitation events in a warmer climate: Results from CMIP5 models, J. Climate, 26, 7902-7911, https://doi.org/10.1175/JCLI-D-12-00850.1, 2013.

Sillmann, J., Kharin, V. V., Zhang, X., Zwiers, F. W., and Bronaugh, D.: Climate extremes indices in the CMIP5 multimodel ensemble: Part 1. Model evaluation in the present climate, J. Geophys. Res.-Atmos., 118, 1716-1733, https://doi.org/10.1002/jgrd.50203, 2013a.

Sillmann, J., Kharin, V. V., Zhang, X., Zwiers, F. W., and Bronaugh, D: Climate extremes indices in the CMIP5 multimodel ensemble: Part 2. Future climate projections, J. Geophys. Res.-Atmos., 118, 2473-2493, https://doi.org/10.1002/jgrd.50188, 2013 b. 
Stein, C. and Malitz, G.: Das Hochwasser an Elbe und Donau im Juni 2013, Berichte des Deutschen Wetterdienstes Nr. 242, available at: http://nbn-resolving.de/urn:nbn:de:101: 1-201310215658 (last access: 8 June 2017), 2013.

Stendel, M., van den Besselaar, E., Hannachi, A., Jaagus, J., Kent, E., Lefebvre, C., Rosenhagen, G., Rutgersson, A., Schenk, F., van der Schrier, G., and Woollings, T.: Two centuries of extreme events over the Baltic Sea and North Sea regions, in: Conference Proceedings of 1st Baltic Earth Conference "'Multiple drivers for Earth system changes in the Baltic Sea region", Nida, Lithuania, International Baltic Earth Secretariat Publication No. 9, 222 pp., 2016.

Uhlemann, S., Thieken, A. H., and Merz, B.: A consistent set of trans-basin floods in Germany between 1952-2002, Hydrol. Earth Syst. Sci., 14, 1277-1295, https://doi.org/10.5194/hess-141277-2010, 2010.

Valiuškevičius, G., Stankūnavičius, G., Stonevičius, E., and Brastovickytė, J.: Change of extreme floods parameters in the Nemunas River lower reaches and delta, in: Conference Proceedings of 1st Baltic Earth Conference "Multiple drivers for Earth system changes in the Baltic Sea region", Nida, Lithuania, International Baltic Earth Secretariat Publication No. 9, 222 pp., 2016.
WAFO-group: WAFO - A Matlab Toolbox for Analysis of Random Waves and Loads - A Tutorial. Math. Stat., Center for Math. Sci., Lund University, Lund, Sweden, available at: http://www.maths. lth.se/matstat/wafo (last access: 8 June 2017), 2000.

Wahl, T., Haigh, I., Woodworth, P., Albrecht, F., Dillingh, D., Jensen, J., Nicholls, R. J., Weisse, R., and Wöppelmann, G.: Observed mean sea level changes around the North Sea coastline from 1800 to present, Earth-Sci. Rev., 124, 51-67, https://doi.org/10.1016/j.earscirev.2013.05.003, 2013.

Wahl, T., Jain, S., Bender, J., Meyers, S. D., and Luther, M. E.: Increasing risk of compound flooding from storm surge and rainfall for major US cities, Nature Clim. Change, 5, 1093-1097, https://doi.org/10.1038/nclimate2736, 2015.

Woldemeskel, F. and Sharma, A.: Should flood regimes change in a warming climate? The role of antecedent moisture conditions, Geophys. Res. Lett., 43, 7556-7563, https://doi.org/10.1002/2016GL069448, 2016. 